\title{
Differences in emotional regulation of Bugis student and Malay cultural background Implications for counseling and guidance services
}

\author{
Nur Wisma ${ }^{1 *}$, Herman Nirwana $^{1}$, Afdal $^{1}$ \\ ${ }^{1}$ Universitas Negeri Padang, Padang, Indonesia \\ *Corresponding author, e-mail: nurwisma8@gmail.com
}

\begin{abstract}
Students often exert an excessive emotional reaction to a problem, thus often acting irrationally. Therefore, students need adequate emotional regulation ability. Factors that affect emotional regulation one of them is culture. This research aimed atdescribing differences in emotional regulation between students of Bugis and Malay cultural background and the implications of counseling services. This research used quantitative method of comparative descriptive type. The sample of this research is students of Bugis and Malay background of RiauUniversityconsisting of 168 students. Purposive sampling was used as the sample technique. The instrument used was an emotional regulation questionnaire with Likert scale model. The results of students' emotional regulation reliability of 0.880 . Data were analyzed using t-test technique. The results of the data analysis showed that the students' emotional regulation in terms of cultural background was clasdified into high category; there is no significant difference which means that no difference between student emotional regulation of Bugis and Malay cultural background.
\end{abstract}

Keywords: Emotional Regulation, Culture, Students.

How to Cite: Wisma, N., Nirwana, H., \& Afdal, A. (2018). Differences in emotional regulation of Bugis student and Malay cultural background Implications for counseling and guidance services. International Journal of Research in Counseling and Education, 2(1), 32-39. https://doi.org/10.24036/0019za0002

\section{Introduction}

Human life undergoes two processes of change: physical and psychological change, the changes follow the stages of development. According to Erikson (in Upton, 2012), the stages of development that individuals pass include: the period of infants 0-18 months, early childhood 2-3 years, preschool period 3-5 years, 6-11 years of school age, adolescence 12-18 years, a young adult period of 19-40 years, a 40-65 year old adult period, and an adult final period of 65 years-die.

The changes are possible to cause psychological problems. Especially during the transition age of late adolescence and early adulthood, this is because in the transition phase it causes new changes that must be passed by the individual. The phase is the stage of development that is passed by the students. This is in accordance with the view of Hurlock (1997) that the period of the development stage of students in general age between 17-24 years. Furthermore, Monk, Knoers, \& Haditono (2001) also suggest that students based on the stage of development are at the age of 18-21 years and 22-24 years old. Therefore, the stage of development is the transition period passed by the students.

Gunawati, Hartati \& Listiara (2006) explain that the transition period experienced by students, encouraging students to face the various demands and new development tasks.The demands and tasks of students development arise because of the changes that occur on some individual functional aspects, namely physical, psychological and social. The changes require students to make adaptation.

Besides, according to Alfian (2014), students also face the pressure due to the process of acculturation with the culture in the place where the students study. Students must face cultural change, lifestyle change, environmental change and students are required to be able to handle them well so that the continuity of 
education also runs well. Because students are not from one region, city or tribe but from almost all regions in Indonesia.

Based on this case, not a few students who fail to do adaptation. Students' failure in adaptation can cause students experience psychological disturbances, such as fear, anxiety, and aggressiveness (Schneiders, in Gunawati, Hartati \& Listiara, 2006).

Guswani \& Kawuryan (2011) say that in Indonesia, the phenomenon of aggressive students behavior often occurs and gets the attention of many parties. The examples of aggressive behavior that occur in Indonesian students today are fights, brawls, anarchist demonstrations, suicide and so forth. These behaviors arise because of the inaccuracy of emotional responses experienced by students.

This is supported by the Central Bureau of Statistics 2016 data on mass fights among students,where in 2008 the cases recorded as 108 with percentage of $0.14 \%$, the year 2011 recorded 210 with $0.27 \%$ percentage, and in 2014 recorded 327 cases with a percentage of $0.40 \%$. It can be seen that mass fights conducted by students every year in Indonesia are increasing. This explains that the degree of inaccuracy of the students' emotional response to something is getting higher.

Basically, emotions strongly help individual life in behaving and acting, but emotions can also have a negative impact if it occurs at the time and intensity as well as provide a inappropriate response.

Hence, negative behaviors will not happen if the students have ability to organize and control emotions which are well known as emotional regulation. Faridh (2015) explains that the ability to manage emotions needs to be done in order that someone can be avoided from antisocial behaviors, especially for adolescents who are experiencing diverse and complex conflicts. The ability to manage his emotion is also called the emotional regulation.

Syahadat (2013) describes emotional regulation is one of the ways that can be done to help individuals facilitate emotional needs. Individuals need to be trained and given a set skill in regulating emotions, so as to judge that emotional feel, manage emotions and express positive and negative emotions correctly. Individuals who are able to perform emotional regulation will elicit positive behaviors and will not lead to negative behaviors.

There are several factors that affect the emotional regulation, one of them is cultural factor. Gross \& John (in Matsumoto, Nakagawa, \& Yoo, 2008) suggest that ethnic groups have differences in regulating the emotions, it can have an influence in interpersonal relationships that indicate the different culture.

This is supported by the results of Pratisti' research (2012) which reveals that a culture providing an opportunity for emotional expression will have an impact on the positive emotional regulation; whereas a culture that is lack of opportunity for emotional expression will have an impact on negative emotional regulation.

Furthermore, emotional regulation is a form of behavior. Lewin (in Alford, 2000) explains that "B $=\mathrm{f}(\mathrm{P}$, E); that is, an individual's behavior (B) is the result of interaction ( $\mathrm{f}$ ) between the personal $(\mathrm{P})$ and the environment (E)". The meaning of the statement above is that behavior is the result of interaction between individuals and their environment; individual or personal is the heredity brought by the individual itself such as the innate or characteristic traits a person possess passed on by the parents through the gene. The environmental factors, namely geograffis, nature, and socio-cultural factors.

Culture is one of the factors that affect the role of men and women in society. Based on this explanation, men and women have different roles, the difference depends on his or her cultural background. Roles certainly affect men and women in behaving (Sari, Nirwana, \& Ahmad). It can also influence how men and women in terms of emotional regulation.

Some tribes well known in Indonesia are Bugis and Malay tribe. Both tribes are known for having the uniqueness of how to communicate and characteristics of the philosophy of life that would affect the way each tribe in solving the problem both personal and group problems, it influences both tribes to respond emotions in facing a problem.

Muhammad (2011) says that Bugis tribe has an open character and does not remain silent, likes to diaspora, adventurous, honest, assertive, respect each other,never give up, faithful, solid and strong establishment, competitive, sportsmanship, high self-esteem ,excellent sailors. On the other word, Bugis tribe has an emotional character, like raging, killing, and willing to die for something. The emotions expended by the Bugis have a reason and the situation should be excluded in the case of maintaining self-esteem. In general, Bugis tribe has a principle of life that is not resigned to the state, solidarity and loyalty, upholdsiri' or self-esteem, and pay attention to manners or manners. 
The Malay tribe also have unique characteristics. Hamidy (1986) explains that there are two things that are known from the Malay tribe, namely (1) Malay tribe is a simple ethnic in appearance and lifestyle. This simplicity sometimes causes stereotypes that the Malaynese people are lazy. Whereas, in fact it is the unambitious attitude and the simplicity of the actions and desires that are so restricted; and (2) Malay ethnic is an ethnic that describes itself as nature. This makes the orientation of life more horizontal than vertical. Therefore, Malay culture is not known of higher or lower status in terms of social stratification. The Malaynese people prefer the harmony, peace, and happiness ofthemselves with the environment compared to their leaders.

When having viewed from the aspect of emotion, Hamidy (1986) explains that the Malay tribe are included as ethnic who have high emotional level, but it can still be seen lower compared to another ethnic in Nusantara. The emotions of the Malay tribe are not so rapidly turning into aggressive emotions. The Malaynese will prefer to avoid rather than fight if something is wrong. The use of figurative words by the Malay tribe is meant to avoid the word that is straightforward in social intercourse, because the Malaynese people believe that a frank submission will degrade the human dignity itself.

In this study, the objectives to be achieved are: (1) Describe the description of student emotional regulation from Bugis and Malay cultural background. (2) Examine the difference of students' emotional regulation from Bugis and Malay cultural background.

\section{Method}

This study used a quantitative approach with a comparative descriptive type. The population of the research was students from Bugis and Malay cultural background in Riau Universitas consisting of 349 students. Determination of sample size using Slovin formula so that get sample 186 and next done withdrawal sample by purposive sampling technique so get the sample as many as 168 . The instrument used was Likert scale. The results of students' emotional regulation reliability of 0.880 . Data are analyzed by using t-test ( $t$ test). To reduce the error rate of data analysisis analyzed by using Statistical Product and Service Solutions (SPSS) program version 20.0.

\section{Results and Discussion}

The data in this study included cultural background variables (Bugis and Melayu) (X), and students emotional regulation $(Y)$. Here is presented the description of research data.

Data on student emotional regulation from Bugis and Malay background were obtained from 168 respondents. Here is the elaboration of emotional regulation data as a whole.

Table 1.Description ofEmotional RegulationViewed fromCultural Background $(\mathrm{n}=168)$

\begin{tabular}{lccccc}
\hline \multicolumn{1}{c}{ Emotion Regulation } & \multicolumn{1}{c}{} \\
\hline Cultural Background & $\mathrm{N}$ & Average & $\%$ & SD & Information \\
Bugis & 76 & 199 & 68.50 & 22.26 & $\mathrm{H}$ \\
Malay & 92 & 196 & 67.67 & 20.08 & $\mathrm{M}$ \\
Whole & 168 & 197 & 68.05 & 21.07 & $\mathrm{H}$ \\
\hline
\end{tabular}

The table 1 above shows that generally the students' emotional regulation is in High $(\mathrm{H})$ category. The highest average (mean) students emotional regulation is students of emotional regulation of Bugis cultural backgrounds with an average score of 199 or $68.50 \%$ of the value of the ideal score, and the lowest average (mean) of students emotional regulation is the emotional regulation of Malaynese students, with an average score of 196 or with a value of $67.67 \%$.

Data of students emotional regulation with Bugis cultural background are 76 respondents. The following is the elaboration of the result of data of emotional regulation of students from Bugis cultural background.

The table 2 above shows that out of the total number of emotional regulation of Bugis cultural backgrounds of students consisting 76 , most of them are in the regulation of emotion category (M) with a total the frequency of 37 students or with a value of $48.68 \%$. Furthermore in the category High $(\mathrm{H})$ frequency amounted to 32 with a value of $42.11 \%$, Very High category (VH) frequency amounted to 4 with a value of $5.26 \%$, and Low category (L) frequency amounted to 3 with a value of $3.95 \%$, and there is no Bugis student who has Very Low (VL) emotional regulation. This can be interpreted that most of the students are quite capable in regulating emotion. 
Table 2. Frequency Distribution and Category of Students Emotional Regulation Score of Bugis Cultural Background $(\mathrm{n}=76)$ and Malay $(\mathrm{n}=92)$

\begin{tabular}{llllll}
\hline Score Interval & Category & \multicolumn{2}{l}{ Frequency $(\mathrm{f})$} & \multicolumn{2}{l}{ Percentage (\%) } \\
\cline { 3 - 6 } & & $\mathrm{B}$ & $\mathrm{M}$ & $\mathrm{B}$ & $\mathrm{M}$ \\
$244-290$ & Very High (VH) & 4 & 2 & 5,263 & 2.17 \\
$198-243$ & High (H) & 32 & 45 & 42.11 & 48.91 \\
$152-197$ & Medium (M) & 37 & 42 & 48.68 & 45.65 \\
$106-151$ & Low (L) & 3 & 3 & 3.95 & 3.27 \\
$60-105$ & Very Low (VL) & 0 & 0 & 0 & 0 \\
Total & & 76 & 92 & 100.00 & 100.00 \\
\hline
\end{tabular}

Furthermore, the total number of students emotional regulation in Malay background is 92 people, mostly in High $(\mathrm{H})$ category with 45 students or $48,91 \%$. Furthermore, in the Medium category (M) the frequency is 42 with $45.65 \%$, Low category (L) frequency is 3 with $3.27 \%$, and Very High category ( $\mathrm{VH}$ ) frequency is 2 with value 2,17\%, and there are no Malay students who have Very Low (VL) emotional regulation. Based on these explanations, it can be interpreted that most students are able to regulate emotions

Furthermore, the detail description of students emotional regulation of Bugis and Malay cultural background based on sub variable of emotional regulation can be seen in Table 3 .

Table 3. Description of Student Emotion Regulation by Sub Variable

\begin{tabular}{|c|c|c|c|c|c|c|c|c|c|c|c|c|c|c|c|}
\hline \multirow{3}{*}{$\begin{array}{r}\text { Sub } \\
\text { Variable }\end{array}$} & \multicolumn{15}{|c|}{ Score } \\
\hline & \multirow[t]{2}{*}{ Ideal } & \multicolumn{2}{|c|}{ Highest } & \multicolumn{2}{|c|}{ Lowest } & \multicolumn{2}{|l|}{ Total } & \multicolumn{2}{|l|}{$\begin{array}{l}\text { Avg. } \\
\text { Aligon }\end{array}$} & \multicolumn{2}{|l|}{$\%$} & \multicolumn{2}{|l|}{ SD } & \multicolumn{2}{|c|}{ Informatior } \\
\hline & & M & B & M & B & M & B & M & B & M & B & M & B & M & B \\
\hline $\begin{array}{l}\text { The ability to not } \\
\text { be affected by } \\
\text { perceived negative } \\
\text { emotions (11) }\end{array}$ & 55 & 49 & 49 & 26 & 27 & 3492 & 2893 & 38 & 38.07 & 69 & 69.21 & 5.16 & 4.09 & $\mathrm{H}$ & $\mathrm{H}$ \\
\hline $\begin{array}{l}\text { Ability to think and } \\
\text { do things well ( } 8 \text { ) }\end{array}$ & 40 & 36 & 36 & 18 & 17 & 2453 & 2110 & 26.7 & 27.76 & 66.7 & 69,41 & 3.84 & 4.20 & M & $\mathrm{H}$ \\
\hline $\begin{array}{l}\text { The ability to } \\
\text { control perceived } \\
\text { emotions (6) }\end{array}$ & 30 & 28 & 27 & 13 & 11 & 1860 & 1550 & 20.2 & 20.39 & 67.4 & 67.98 & 3 & 3.08 & M & M \\
\hline $\begin{array}{l}\text { Individual } \\
\text { confidence to deal } \\
\text { with a problem (4) }\end{array}$ & 20 & 17 & 19 & 5 & 7 & 1186 & 1013 & 12.9 & 13.33 & 64.5 & 66.64 & 1.77 & 2.35 & M & M \\
\hline $\begin{array}{l}\text { Ability to find a } \\
\text { way that can } \\
\text { reduce negative } \\
\text { emotions (5) }\end{array}$ & 25 & 25 & 24 & 12 & 9 & 1701 & 1332 & 18.5 & 17.53 & 74 & 70.11 & 2.75 & 3.51 & $\mathrm{H}$ & $\mathrm{H}$ \\
\hline $\begin{array}{l}\text { Rapid ability to } \\
\text { calm down after } \\
\text { experiencing } \\
\text { excessive emotion } \\
\text { (4) }\end{array}$ & 20 & 19 & 19 & 9 & 9 & 1291 & 1041 & 14 & 13.7 & 70.2 & 68.49 & 2.12 & 2.39 & $\mathrm{H}$ & $\mathrm{H}$ \\
\hline $\begin{array}{l}\text { Ability to respond } \\
\text { to the displayed } \\
\text { emotions } \\
\text { (behavioral } \\
\text { responses, } \\
\text { physiologicaland } \\
\text { tone of voice)(9) }\end{array}$ & 45 & 40 & 41 & 18 & 18 & 2735 & 2276 & 29.7 & 29.95 & 66.1 & 66.55 & 4.6 & 4.85 & M & M \\
\hline $\begin{array}{l}\text { The ability to show } \\
\text { the right emotional } \\
\text { response (11) }\end{array}$ & 55 & 50 & 50 & 25 & 26 & 3344 & 2883 & 36.3 & 37.93 & 66.1 & 68.97 & 4.67 & 5.24 & M & M \\
\hline Whole & 290 & 245 & 248 & 149 & 147 & 18055 & 15098 & 196.3 & 198,7 & 67.67 & 68.5 & 20.08 & 22.26, & M & $\mathrm{H}$ \\
\hline
\end{tabular}

The table 3 above shows that the students' emotional regulation with Bugis cultural background is mostly sub variable in High $(\mathrm{H})$ category with the highest overall score reached 248 from the ideal score of 290 . The overall lowest score is 147 , the total score reaches 15098, the average score of 198.7 with the overall achievement level of respondents emotional regulation of students Bugis cultural background of 68.5\% with standard deviation on the value of 22.26. Based on the table above can be concluded that the emotional regulation of Bugisnese students are in the High category $(\mathrm{H})$. 
For the highest score of the average student's emotional regulation Bugis cultural background lies in the sub-variableability ability to find a way that can reduce negative emotions with a value of $70.11 \%$, then the lowest average score is in the sub variableability to respond to emotions displayed (response behavior, physiological and tone of voice) of $66.55 \%$.

Furthermore, the students emotional regulation with the Malay cultural background of most subvariables is in the Medium (M) category with the highest overall score reached 245 from the ideal score of 290. The overall lowest score is 149 , the total score reaches 18055 , the average score is 196,3 with the overall achievement level of student emotional regulation respondentswith Malay cultural backgroundof $67.67 \%$ with standard deviation at 20.08.Based on the above statement, it can be concluded that the Malaynese students emotional regulation is in the Medium category (M).

The detail results of data analysis, the highest score of the average students emotional regulation of Malay cultural background lies in the sub-variableability to find a way that can reduce negative emotions with a value of $74 \%$, then the lowest average score is in the sub-variable of individual beliefs to solve the problem with a value of $64.5 \%$.

Based on data analyzed by using PSS version 20.00, it is obtained the normality and homogeneity testing results as follows:

Tabel 4.Test of Data Normality of Emotional Regulation of Students

\begin{tabular}{lllll}
\hline Variables & \multicolumn{2}{c}{ Kolmogorov-Smirnov } & Information \\
\cline { 2 - 4 } & KSZ & Df & Sig. & \multirow{2}{*}{ Normal } \\
\hline
\end{tabular}

The result of normality test analysis based on Table 3 can be concluded that emotional regulation variable has Asympscore.Sig.ie 0.480 is greater than the predetermined significance level of 0.05.That is, the data from the emotional regulation variable are normally distributed.

Tabel 5. Homogeneity Test of Emotional Regulation Data College students

\begin{tabular}{llllll}
\hline \multicolumn{1}{c}{ Variables } & Levene Statistic & $\mathrm{df1}$ & $\mathrm{df2}$ & Sig. & Information \\
\hline $\begin{array}{l}\text { Emotion } \\
\text { Regulation }\end{array}$ & 0.466 & 1 & 166 & 0.496 & omogeneous \\
\hline
\end{tabular}

Based on Table 5, it can be concluded that emotional regulation variable has Asympscore.Sig. 0.496 is greater than the significant level that has been set that is 0,05 . That is, the data from students' emotional regulation variable with the background of Bugis and Malay cultural bacground is homogeneous.

Based on the results of normality and homogeneity test show that the requirements of thet-tes have been met. If it is viewed from entirety, it can be concluded that can be seen in Table 6.Based on Table 6 can be drawn conclusion research as follows:

Independent Samples Test

\begin{tabular}{|c|c|c|c|c|c|c|c|c|c|}
\hline & & & & & & st for Equali & f Means & & \\
\hline & & $\mathrm{F}$ & $\mathrm{T}$ & df & $\begin{array}{l}\text { Sig. (2- } \\
\text { tailed) }\end{array}$ & $\begin{array}{c}\text { Mean } \\
\text { Difference }\end{array}$ & $\begin{array}{l}\text { Std. Error } \\
\text { Difference }\end{array}$ & $\begin{array}{l}95 \% \text { Confi } \\
\text { the }\end{array}$ & $\begin{array}{l}\text { hterval of } \\
\text { hce }\end{array}$ \\
\hline & & & & & & & & Lower & Upper \\
\hline $\mathrm{RE}$ & $\begin{array}{l}\text { Equal } \\
\text { variances } \\
\text { assumed }\end{array}$ & ,696 & ,713 & 166 & ,477 & 2,332 & 3,270 & $-4,124$ & 8,787 \\
\hline & $\begin{array}{l}\text { Equal } \\
\text { variances not } \\
\text { assumed }\end{array}$ & & ,706 & 152,786 & ,481 & 2,332 & 3,302 & $-4,192$ & 8,855 \\
\hline
\end{tabular}

Table 6 can be used to see the differences on students emotional regulation of Bugis and Malay cultural background. If the value of tcount is greater of ttable and the value of P-value is smaller than 0.05 then declared has the same meaning as vice versa. Based on Table 6 , the value of tarithmetic is smaller than ttable and the value of P-value is greater than the significant level of $0.477>0.05$, otherwise there is no significant 
difference between students emotional regulation cultural backgrounds of Bugis and Malay but on average Bugis cultural students produce higher emotional regulation scores compared to Malay students.

\section{Discussion}

Based on the results of data analysis reveal that the students emotional regulation of Bugis cultural background is in High category $(\mathrm{H})$ and Malay culture is in Medium category (M). If it is viewed in detail the emotional regulation of Bugis students on sub-variable ability to find a way that can reduce negative emotions have the highest average. Then on the sub variableof individual confidence to be able to solve a problem get the lowest average score. Malay students emotional regulation highest average score also lies in sub variable ability to find a way that can reduce negative emotions.

The results of the research on this variable reject the results of previous research with respect to the existence of different emotional regulation in terms of culture. This is natural, because the students of Bugis cultural background are sampled in this research has experienced acculturation of culture.

The absence of significant differences in emotional regulation of Bugis and Malay students is allegedly related to Bugis tribe characters known as nomads, especially in male students. In accordance with the opinion expressed by Ahmad (2017) that Bugis people since centuries famous to have the soul of the nomads. In Bugis society, sailing, wandering, trading, and wandering is a whole tradition in their life.In line with that, Rusli (2015) states that the culture of Overseas is a character of Bugis people since time immemorial.As a tribe of nomads, Bugis tribes come to various places of course with a culture attached to him.One of the main values of Bugis culture is the concept ofsiri 'na pacce / pessewhich is used as the philosophy of life and the source of inspiration of their behavior in social life.

Furthermore, Hamid (in Rusli, 2015) suggests that the implementation of the concept ofsiri na paccein overseas lands by Bugis tribe includes: (1) high solidarity, (2) persistence in work, (3) responsible(5) sensitive to the fate of others, (6) high awareness of religious development and education, (7) high appreciation of local culture, and (8) keeping the peace.

The things above are supported by Koentjraningrat (1996) which suggests that acculturation is related to the concept of social processes that occur if a set of human beings with special culture confronted with elements of a foreign culture, and these elements slowly accepted into the culture itself without losing the personality of its own culture.

The explanation is supported by Berry (in Rahmah, 2015) saying that acculturation is a process which captures the culturaland psychologicalchangesthat take placeas a resultcontact between two or more cultural groups andits members.At the acculturation group level involves a changeinsocial structures and institutions.While at the level of individual acculturationinvolves behavior change.

Shifting values on the culture that occurs in the studentscause a shift in valueresulting in behavioral changes and itbecomesa strong factorsuspectedininfluencing the way students in managing or managing their emotions, thus causing the non-acceptance of hypotheses in this study.

Based on the above opinion, it is reasonable that Bugis and Malay students have no significant difference in emotional regulation, this is because the characteristics of Bugis students known as nomads must have been taught by their cultural background regarding the adapatation that must be done in a new environment. Allegedly, this is what causes the emotional regulation of Bugisnese students on average is higher than Malaynese students.

However, in addition to cultural acculturation factors experienced by students there are other factors that influence the emotional regulation of Bugisnese and Malaynese students. Some research from experts reveal that there are internal and external factors that affect a person's emotional regulation. The factors in between predisposing from such individuals as individual personality types themselves. Furthermore, the age factor, parenting style, and friends.

This is supported by Nisfiannor \& Kartika (2004) who argue that emotional regulation is affected by one's age. It is supported by Urry \& Gross (in Arviyenna, 2015) the age of a person is associated with the enhancement of emotional regulatory capacity, where the higher the age of a person, the better the regulatory capacity. Furthermore, Banerju (in Nisfiannor \& Kartika, 2004) reveals with the need of affectin children, then parents have influence on the child's emotional life-her son. Furthermore, Havilland (inNisfiannor \& Kartika, 2004) reveals that emotional regulation is influenced bypeer groupsor peer groups.

\section{Implications}

The results of research related to students emotional regulation in terms of cultural background show that in general students have been able to regulate their emotions. But, there are still students who have moderate and low emotional regulation.

Therefore, the results of this study can also be used as an input for counselors in universities in addressing the students emotional regulation. Counseling guidance service is indispensable to improve emotional regulation among students. Counselors are expected to make programs related to the improvement of the 
ability of students to control their emotions. The lowers indicator on the results of this study such as individuals beliefs to be able to solve a problem can be used as a references to create counseling and guidance program and directed to the field personal and social engagement.

Based on the the findings, there are several things that can be done from the guidance and counseling among the counselors to actively discuss in the procurement of guidance counseling unit in universities so that with the guidance counseling unit on campus students have a place to implement. In addition, counselors can also provide counseling services to students regarding how to improve emotional regulation capabilities such as information services, group counseling services, group guidance services and so forth. This case can be administered in the form of trainings in collaboration with the organization parties on campus.

\section{Conclusion}

It is hoped that active counseling personnels will participate in training related to counseling, especially to deepen the science of cross-cultural counseling so that the conselor will be able to understand the psychological aspects of clients with different cultural background so that in the implementation of counseling there will be no cultural biases that will result in ineffective counseling process.

It is expected that students are able to improve their ability to interact well with diverse cultural environment so that the students are indirectly trained to improve their emotional regulation. Students will actively participate in activities related to the improvement of daily effective day-to-day.

Researchers are expected to deepen the causes of aggressive cases that occur on the students, so it can find other factors causing the case. Another researchers are also expected to pay attention on the background of the subject used as a research sample, so that the research objectives can be achieved.

The implementation of counseling in universities requires a container, so the implementation of counseling can run effectively. Therefore, the campus is expected to provide facilities in the form of Guidance and Counseling Services Unit. It is expected that organizational leaders are more active in collecting members from different cultures, so that the data can be used properly. Furthermore, the leader is expected to actively carry out activities related to their respective cultures.

\section{References}

Afdal, A., Elviana, E., \& Alizamar, A. (2017). The Role of Counselors in the Development of Career Planning for Youth Inmates. GUIDENA: Jurnal Ilmu Pendidikan, Psikologi, Bimbingan dan Konseling, 7(2).

Afdal, A. (2015). Kolaboratif: Kerangka Kerja Konselor Masa Depan. Jurnal Konseling dan Pendidikan, 3(2), 17.

Alfian, M. (2014). Regulasi Emosi pada Mahasiswa Suku Jawa, Suku Banjar, dan Suku Bima. Jurnal Ilmiah Psikologi Terapan, 2(2), 263-275.

Alford, S. M. (2000). A Qualitative Study of the College Social Adjustment of Black Students from Lower Socioeconomic Communities. Journal of Multicultural Counselin and Development, 28(1), 2-15.

Ardi, Z. (2014). Cita-cita Perkerjaan dan Pilihan Peminatan Siswa Sekolah Menengah Atas Negeri di Sumatera Barat.

Ardi, Z., \& Yendi, F. M. (2017). Students Attitude Towards LGBTQ; the Future Counselor Challenges. Jurnal Konseling dan Pendidikan, 5(2), 74-79.

Ardi, Z., Ibrahim, Y., \& Said, A. (2012). Capaian Tugas Perkembangan Sosial Siswa dengan Kelompok Teman Sebaya dan Implikasinya terhadap Program Pelayanan Bimbingan dan Konseling. Konselor, 1(2).

Arviyenna, S. (2015). Hubungan antara Parent Attachment dengan Regulasi Emosi Remaja di SMA Negeri 5 Surakarta (Doctoral dissertation, Program Studi Psikologi FPSI-UKSW)

Brenner, F., \& Salovey, T. L. (1997). Parental Socialication of Emotion. Journal Sychological Inquiry, 9, 241-273.

Daharnis, D., \& Ardi, Z. (2016). The Compatibility Student Choice of University Majoring; a Preliminary Studies. GUIDENA: Jurnal Ilmu Pendidikan, Psikologi, Bimbingan dan Konseling, 6(1), 101-109.

Faridh, R. (2015). Hubungan antara Regulasi Emosi dengan Kecenderungan Kenakalan Remaja. Naskah Publikasi. Yogyakarta: Universitas Islam Indonesia. Diakses tanggal, 1.

Gunawati, R. Hartati. S., \& Listiara, A.(2006). Hubungan antara Efektivitas Komunikasi Mahasiswa-Dosen Pembimbing Utama Skripsi dengan Stress dalam Menyusun Skripsi pada Mahasiswa Program Studi Psikologi Fakultas Kedokteran Universitas Diponegoro. Jurnal Psikologi Universitas Diponegoro, 3(2). 
Hamidy, U. (1986). Membaca Kehidupan Orang Melayu di Riau. Pekanbaru: Bumi Pustaka.

Hurlock, E.B. (1997). Psikologi Perkembangan: Suatu pendekatan sepanjang rentang kehidupan. (terjemahan Istiwidayanti dan Soedjarwo). Jakarta: Erlangga.

Koentjaraningrat. (2009). Pengantar Ilmu Antropologi. Jakarta: Rineka Cipta.

Matsumoto, D., Yoo, S. H., \& Nakagawa, S. (2008). Culture, Emotion Regulation, and Adjustment. Journal of Personality and Social Psychology, 94(6), 925.

Monks, F. J., Knoers, A. M. P., \& Haditono, S. R. (2002). Psikologi Perkembangan: Pengantar dalam berbagai bagiannya, (terjemahan oleh Sri Rahayu Haditomo) Yogyakarta: UGM.

Morris, A. S., Silk, J. S., Steinberg, L., Myers, S. S., \& Robinson, L. R. (2007). The Role of the Family Context in the Development of Emotion Regulation. Social Development, 16(2), 361-388.

Muhammad, A. (2011). Membaca Karakter Orang Berdasarkan Etnisnya. Yogyakarta: Najah.

Nisfiannoor, M., \& Kartika, Y. (2004). Hubungan antara Regulasi Emosi dan Penerimaan Kelompok Teman Sebaya pada Remaja. Jurnal Psikologi, 2(2), 160-177.

Pratisti, W. D. (2012). Peran kehidupan emosional Ibu, Budaya dan Karakteristik Remaja Pada Regulasi Emosi Remaja. Proceeding.

Rahmah, N. (2015). Akulturasi pada Mahasiswa Asing di UIN Suska Riau (Doctoral dissertation, Universitas Islam Negeri Sultan Syarif Kasim Riau).

Ratnasari, S., \& Suleeman, J. (2017). Perbedaan Regulasi Emosi Perempuan dan Laki-laki di Perguruan Tinggi. Jurnal Psikologi Sosial, 15(1).

Restu, Y., Yusri, Y., \& Ardi, Z. (2013). Studi Tentang Perilaku Agresif Siswa di Sekolah. Konselor, 2(1).

Yanti, S., Erlamsyah, E., Zikra, Z., \& Ardi, Z. (2013). Hubungan antara Kecemasan dalam Belajar dengan Motivasi Belajar Siswa. Konselor, 2(1). 